\title{
Self-surveillance in French Colonial West Africa: French Intelligence Services and the Hamallist Information Network (1910-1943)
}

\author{
CISSE Chikouna \\ University Félix Houphouet Boigny, Abidjan, Ivory Coast
}

\begin{abstract}
In this article, with the use of the Agency mode, I try to shed light on the resilient capacity of African societies to the foreign inroad in the 20th century. In 1910-1940, the success of Hamallist Information Networks to beat the French imperial machinery in the Nioro of the Sahara located in the French Sudan (known as Mali nowadays), leads to reconsidering the power relationship organizing the authority and the challenge to establish the authority relation during colonial period. That calls into question the idea of a sole and unique domination by French imperialism during colonization and at the same time, it indicates that indigenous people were very active in the historical processes, which determined their existence.
\end{abstract}

Key words: French colonial, Africa intelligence services, Hamallist network information

\section{Introduction}

"Hammallah criticizes the administration for its surveillance system and tends to ignore that he has got himself one of the most active secret services". This extract from the report of the 1937's interview between Mr. Bouscayrol, the assistant administrator of the circle of Nioro (colonial Sudan) and the Sheriff Hamallah, tackles the issue of the degree of distrust existing between the French colonial administration and the Sheikh Hamallah, the figurehead of the Hamallist brotherhood and Islam in the 20th century in Africa. In connection with Hamallism and its organization, the term "secret services" undoubtedly overused, sheds considerable lights on the powerlessness of the French colonial power to the resilient capacity of a religious order it finds hostile.

The present contribution mainly intends to highlight the ways through which the conflict, in the field of inquiries, moves around between the colonial administration and the Sheikh Hamallah who, owing to his resistance to colonization, was distrusted by the colonial power when he took control over religious matters in the Nioro of the Sahara in 1910s. Aiming to maintain in order the Sudanese Sheikh and his followers who rather worried about how to survive in the context of a foreign domination, the colonizer put inquiries in all places at the center of its strategies. Accordingly, if thanks to previous works by scholars and the historical archives or the Public Record Offices, the imperial side of inquiries is more or less known, it now remains to provide with documents the other one set up by the colonized people so that to set the divided lines in the most widespread idea of a process thoroughly controlled by the colonial power. The sources available in the French colonies of West Africa as well in Senegal, Côte d'Ivoire and Mali and the collected oral sources in those three

CISSE Chikouna, Ph.D., Associate Professor, History Department at Félix Houphouet-Boigny University of Cocody-Abidjan. 
countries are of a great help in implementing "a comprehensive history" which accounts for the social and cultural indexes the Hamallists used to defeat institutional inquiries.

\section{Circumventing the Machinery of the Imperial Force by Means of Inquiries: The Administration of Colonial Sudan to the Hamallist Counter-Information Network}

On December 21st 1925, the superintendent, the head of the department responsible for the security of colonial Sudan, sent a letter to his superior. Here is the content:

I am writing to inform you about that around 2 and 4 am, about fifteen indigenous people gathered in Niarela at M. Kalifa Dramé, the Sheriff Hamallah's adviser in Bamako. The intelligence service agents found no admittance in the house because each person was identified when they arrived and the door was also locked after the last person entered. From outside, the agents could see them whispering the Salam and holding a meeting after the prayer but they failed to catch what was being said. Due the darkness in the house, they did not succeed to identify the participants but argued that the Sheriff Hamallah did not attend the meeting ${ }^{1}$.

The failure while tempting to infiltrate a meeting by the Sheikh Hamallah's followers in Bamako proves very well the existence of an imperial arrangement to keep a watch over Hamallah and his religious brotherhood tijaniyya hamawiyya which was on bad terms with the French colonial administration in Sudan from 1920 to 1940. Additionally, it shows how able were the dominated people to defeat the imperial spirit by finding alternative ways out to the colonial pitfalls whose keystone was consisted of surrounding conquered spaces with violence and the defeated spirits and bodies as well. What is called in the modern French educational system by Foucault as "the political economy" of the body $(1975$, p. 33), unveils flawlessly the metamorphosis of the machinery of the imperial police in the French colonies of West Africa. Bénédicte Brunet-La Ruche underlined it by showing that from 1920 to 1930 in Dahomey (known as Benin nowadays), we moved from a logic of "pacification" to the one of surrounding people and places so as to put under tight surveillance and "bring under control" the whole urban colonial space (Brunet, 2012, p. 22).

When considered this way, the practice of inquiries shows how trustworthy it is to keep a watch over and punish (Foucault, 1975) the ones by indigenous, political and religious leaders like the Sheikh Hamallah, who resisted to a foreign occupancy, whose life was punctuated by a large number of deportations and exhausted the punishment choices of the machinery of the colonial repression. The three terms: inquiries, surveillance and repression then became the kernel of the French administration policy against Islam in the French colonies of West Africa. In 1906, the Governor General made a plea for creating a true Islamic proselytism index through the establishment by each marabout ${ }^{2}$ of an individual certificate containing useful information such as their birthplace, age, past history and everything they said and did, etc. ${ }^{3}$ Those so called certificates aimed at differentiating the Muslim leaders that were for or against the French colonial order in Africa. That system of control and repression installed in the French colonies of West Africa looks like the Arabic offices created in Algeria which essentially targeted to set up a French order in the country (Frémeaux, 1993, p. 129). Those ones strove hard to list the most powerful brotherhoods of the region as well as in the tribe and identify the names of their different rulers (Frémeaux, 1993, p. 129).

\footnotetext{
1 The Malian Public Record Office. Koulouba $4^{\mathrm{E}} 4$. Political reports. Letter from December 21st 1925.

2 Mostly speaking, he is known as a Muslim MKO who operates some miracles.

3 The Surveillance of Islam. The setting up of an index of Muslim proselytism in French Colonies of West Africa. The Governor General to the Governor-Lieutenants of Cote d'Ivoire, Senegal, of High-Senegal-Niger, colonial Guinea, Dahomey and to the Commissioner of the Governor General in Mauritania. Dakar, December 26th 1911. Non listed Record of Nioro.
} 
Coming back to our track, in early 1923, the Captain Andre whose different reports initiated the repression policy against the Sheriff Hamallah (Savadogo, 2012) suggested that in addition to the listening agents like Dupuy Yacouba, the Director of the Muslim denominational school in Timbuktu, a liaison officer be designated who will work on behalf of the political department of the Governor of Sudan. His work would consist in spying on every circle by looking for information the intelligence services could be interested to ${ }^{4}$.

Once more, in 1925, in spite of the large number of people recruited in "indigenous" milieus for providing the administration with information, the Governor Descemet came to the conclusion in his lengthy report that keeping a watch over the Sudanese Sheikh and his means of action (Traoré, 1983, p. 240), was a very hard work. The French administration had various people that provided it with information. Amongst others, were the marabouts of rival brotherhoods, the Moorish fractions opposed to the Sheriff Hamallah such as the marabout Idei boussat from Boumdeit Cheikh Mohamed Abdallahi, a follower of the Qadriya brotherhood and was he who gave a favorable reception to the Tinouajiou and fought the Hamallists. He also charged the Sheriff with being responsible for the disturbance that occurred in the borders of Assaba-Sudan. There were also, civil servants like Mamadou Diawara, the Manager of both companies Ch. PEYRISSAC and Cie in Kidira (Senegal), Seydou Nourou Tall's student and Seydou Nourou Tall himself, the prominent figures of 12 Rosary beads Tijaniyya, the travelers who stopped over the River Senegal, etc.

If some agents succeeded to infiltrate the places where the Hamallist peddlers could be found, the others rather chose to become Hamillists themselves for the sake of making inquiries in a zaouïa ${ }^{5}$. However, while tempting to do harm to a religious opponent, the Sudanese Sheikh, the administration faced many difficulties in so doing because it failed to differentiate accurate information from inaccurate ones. In July 1937, the commander even complained about that situation. He argued that whenever information was provided, they came from Hamallists' opponents, the 11 Rosary beads ${ }^{6}$ especially the Sheikh Turad, the chief of Talib Mukhtar's tribe, a follower of Qadiriyya and the main provider with information of the administration in the Hodh $^{7}$.

This gap noticed from the institutional inquiries in 1920-1930 is a strong contrast to the wonderful Hamallist counter-information network not necessarily meant for rebelling against the French colonizer but rather anticipating their moves in order to protect the Sheikh Hamallah from the repression of the French administration in Sudan. If he was very learned about the relevance of inquiries in the conflict opposing him to the French, but the Sheriff is not presented as the forerunner of a system of inquiries he designed to meet his purposes when regarding oral sources and historical archives. In 1937, while exchanging with the commander of the circle of Nioro, Hamallah declared that he did on purpose by not allowing his followers to provide information because he had religion as his sole and unique business and also he did not want his companions to be involved in political matters. ${ }^{8}$ Actually, the repression was so intensified against them that, Hamallah and

\footnotetext{
${ }^{4}$ The Senegalese Public Record Office 19G23 (108). Report about the indigenous people mindset in colonial Sudan from the Captain P. J. ANDRE, Responsible for the Intelligence Services and Islamic affairs (The carrying out of the order $n^{\circ} 847$ from the Governor General). Koulikoro, August 10th 1923. Suggestions for improving the Organization of the Intelligence Services in Sudan, p. 51.

5 Ahmadou Hampaté Bah interviewed by El Hadj Sacko. Oral tradition dictated by A. H. Bâ to H. Heckmann (Shorthand notes, then typed up), on June 15th 1969 (at Villa d'Avray). The zaouïa is the place where the followers of Tijaniyya gather for their worship.

6 This is another word to call the Hamallists which distinguishes them from their Omarian opponents known as twelve Rosary beads.

7 (ANM, $4^{\mathrm{e}} 26$, the report of inquiries of the circle of Nioro, July 1937. Confidential).

8 The circle of Nioro. August 23rd 1937. From the Commander of the circle of Nioro to the Governor of Sudan. Koulouba. Reference: letter n`534 A.P from July 21 st 1937 concerning the Sheriff Hamallah. Confidential. Non listed record of Nioro.
} 
his followers had no other ways out but only resorting to inquiries to defeat the moves of the administration. Hence, they became the protagonists of the processes organizing the authority and the challenge to establish the authority relation.

Brotherhood, when approached on a diversified and multiethnic perspective which is unlike the one that is widely spread across West Africa (Piga, 2006) and very far from it in terms of space (Traoré, 1983; Piga, 2006; Soares et Launay, 2009), brought about some branches amongst natives from Nioro and its surroundings. Those branches would play key roles in the conflict between Hamallah and the French. As fate would have it, the Sheriff Hamallah would find some allies in the French administration allowing him to escape the machinery of the imperial police. In accordance with some information from the Head of the department responsible for the security of the colonial Sudan, those allies were essentially his followers working as civil servants in the Nioro of the Sahara where all the indigenous civil servants were Hamallists except one working at TSF ${ }^{9}$. Since this time, the French administration had become very cautious and considered any "indigenous" civil servant as someone who provided Sheikh Hamallah with information.

In account of the fact that they were said to be tied to Abadi Haidara, a close friend of Hamallah, the agents Bouye and Ely Diallo, the primary school teacher Mamadou Diarra, the Arabic editor Seydou Semega and the interpreter Paul Haidara were suspected of providing the Sheriff with information. Consequently, the administration was subject to "a purge" so as to take away the "indigenous" agents suspected of plotting with the Sheriff.

According to the Governor, Mahamadou Doukoure, the presiding judge of the Court of First Instance in the circle of Nara was dismissed for having involved himself in some matters with the Sheriff Hamallah ${ }^{10}$. In Bamako, because he was allied with the Sudanese marabout ${ }^{11}$, it was suggested that the main assessor of the Court of First Instance, Gaoussou Kouroumaka be replaced. As for the Sheikh Alaji Tambadou, after visiting the Sheriff Hamallah ${ }^{12}$ in the Nioro of the Sahara, he decided to resign as assessor in the Court of subdivision of N'guenar (Senegal). The time the Sheriff Hamallah was exiled in Cote d'Ivoire (1930-1935) greatly increased the mobility of his followers and the extension of the Hamallist network rendering more difficult institutional inquiries than ever.

\section{Repression and the Hamallists' Spread out in the French Colonies of West Africa or Inquiries Through Migration (1930-1940)}

On February 15th 1930, the cruel conflict occurred in Kaedi in the Southern part of Mauritania ${ }^{13}$ causing the Hamallists to spread out in the French colonies of West Africa after, would extend their information network in the conflict opposing him to the French administration. Unlike the machinery of the imperial force, the brotherhood got now bigger and went beyond the borders of his former headquarter, the Nioro of the Sahara.

\footnotetext{
${ }^{9}$ Non listed record from the circle of Nioro. Inquiries. Stamped SECRET. File collected by the Administrator of the circle of Nioro at the Investigation Department of Bamako (indigenous people registration forms).

${ }^{10}$ The Malian Public Record Office. Koulouba $4{ }^{\mathrm{E}} 4$ letter $n^{\circ} \mathrm{A}-478$ from November 25 th 1925 . Sent by the Governor of the colony to the Commander of the circle of Nara.

${ }^{11}$ The Malian Public Record Office. Koulouba $4{ }^{\mathrm{E}} 4$ letter $n^{\circ} \mathrm{A}-479$ from November 25 th 1925 . Sent by the Governor of the colony to the Commander of the circle of Nara. +5 .

${ }^{12}$ The Malian Public Record Office. Koulouba $4^{\mathrm{E}} 4$. A copy of the registration form concerning the man who is called Sheikh Aladji Tambadou, registration started on September 1st 1925.

${ }^{13}$ On February 15th 1960, the pro-Hamallah supporting Yacouba Sylla, a follower of the Sheikh Hamallah fought against their Omarian opponents. That violence had caused about 50 supporters from both sides to die. Those ones were shot at point-blank range by colonial circle watchmen or died at hospital from their wounds later on.
} 
Consequently, the Hamallist network gained an acceptance in each French colony of West Africa owing to the migration of Hamallah's followers to the colonial Sudan, Senegal, Mauritania, Niger and Cote d'Ivoire where the Sheikh Hamallah was sent to jail from 1930 to 1935.

The spread Hamallist information network in the aforementioned territories remained the places where Hamallah's followers whatever they be prisoners or not, shared information and guidelines. Anna Pondopoulo shows that the way Muslims and their ideas moved around across territories and borders, reveals undoubtedly a reality the French administration interpreted according to its own view (Pondopoulo, 2010): the one of a religious irredentism which, by the domino effect would likely bring together as one all the Muslim movements opposed to the French occupancy in West Africa.

In order to remedy that situation, the colonial administration would keep a close watch over the written letters in Arabic that the Sheikh Hamallah and his followers sent to each other. Some would be fiery diatribes against the colonial order while news about the brotherhood and its main ruler, news about the followers' mindset, the living conditions of the families of people sent to jail, fund raising in favor of the Sheikh Hamallah, allegiance to him and odes to his glory, for the others. All those letters would be closely watched over by the French administration, which one because it still cast a doubt to the brotherhood, would do its utmost to get those letters translate into French for better understanding and having a clear cut idea about Hamallah's mindset vis-à-vis France.

In 1930, being unable to find skilful translators for the letters intercepted, the French administration was compelled to make some drastic decisions. Those ones aimed at no longer allowing Mr. Kaba Sylla and Mr. Amady Gata, some Hamallists living in exile to send some letters to any Muslim living in Cote d'Ivoire and the Sheriff Hamallah who was thought to be an influent and dangerous person.

Then, in Abengourou, the Administrator was commanded to send first all the letters for his prisoners to his superior in the aim of getting them control by the Governor General's Intelligence services which will then appreciate whether they can be given back without any danger to the people they intended to ${ }^{14}$. In 1937, in the colonial Sudan, Baye Doukoure, a staunch Hamallist was arrested while possessing fourteen books, 138 letters, poems and various writings of the like by the commander of the circle of $\mathrm{Nema}^{15}$.

This will not cause Hamallah's followers to give up. They continued sending letters to each other but the senders no more used the colonial post offices. For instance, amongst the letters found with Baye Doukoure, the one marked as number 35 was sent to himself by Bakary Doukoure asking the latter to send him some poems about Hamallism and Arabic books. He did not forget about giving him some guidelines in the letter so as to avoid that the letter be sent through the post office but rather it be given to a reliable person ${ }^{16}$.

In 1943, the Hamallist Abdoulaye Mossi used this modus operandi. While traveling, he stopped by Nioro where he brought some letters from one of his brothers in Bamako. Those letters were about giving money to a well-known Hamallist and some gifts for Zeinabou Mint Souedat, Hamallah's wife living in Nioro and Assa Diarra, his maidservant ${ }^{17}$.

\footnotetext{
14 The Ivorian Public Record Office X-13-253-9245. Political prisoners deported from Sudan and Mauritania to Cote d'Ivoire. 1930-1934. Telegram-letter n³94 from the Lieutenant-governor of Cote d'Ivoire to the Administrator of Abengourou. Bingerville, November 17th 1934.

${ }^{15}$ ANM $4^{\mathrm{E}} 24$ Telegram-letter. The Circle of Nema to the Subdivision of Mourdiah, $\mathrm{n}^{\circ} 80 \mathrm{C} / \mathrm{C}$ from August 18th 1937.

16 ANM 4 ${ }^{\mathrm{E}} 24$ Telegram-letter. The Circle of Nema to the Subdivision of Mourdiah, ${ }^{\circ} 80 \mathrm{C} / \mathrm{C}$ from August 18th 1937.

17 ANM (FR) $1^{\mathrm{E}} 2$. The general report tackling the political face of Sudan in March-April 1943.
} 
The oral sources collected from Adzope (Cote d'Ivoire) by Alioune Traore, a well-known specialist of Hamallism show that from Sudan and Mauritania, any letter and gift intended to the Sheriff was sent to Sidati Ould Baba Ainina, a Mauritanian living in Abidjan. The letter was then sent to Adzope by someone known as Balo Moussa who in his turn will give it to the male nurse of the Sheikh Hamahoullah.

When his days in Adzope drew to their end, the marabout was allowed to send one of his companions for shopping in the town. That companion was Bilali who used to go shopping for him. Very frequently, this man met with Sidati Ould Baba Ainina in the market of Adzope to take the clandestine letters intended to the Sheikh (Traoré, 1983).

For the sake of defeating the machinery of institutional surveillance, certain followers will set up another strategy of inquiries. This was a sort of missi dominici, that shuttling back and forth between the headquarters of the Hamillist movement located in West Africa. During the 1930's great spreading out, those ones so became not only very active agents that strengthened the Hamallist networks but also means by which the followers and their ruler were provided with information.

The man called Oumar Sylla also well-known as "Oumar, the mailman"18 played a similar role to the Sheriff Hamallah during the time he spent in prison in Adzope. He kept the Sheikh Hamallah in touch with his family and some of his arrested followers like the famous Yacouba Sylla ${ }^{19}$. If putting an end to the Sheikh's exile in Cote d'Ivoire indicates a shaping of colonial authorities' mindset, now ready to abandon the fighting policies they had been implementing since 1920 in favor of pacification (Joly, 1997), but his moves will still be kept watching over. He was back from his exile in Cote d'Ivoire with a prestige that went increasingly. Then worried, the administration of Nioro decided to tighten the machinery of surveillance meant for keeping a watch over someone that is viewed by "indigenous" people as a victim from colonization.

However, in 1925, the French administration agreed to say that it was provided with inaccurate information about the brotherhood. ${ }^{20}$ This was the testimony of the failure of institutional inquiries. While going back to the old attitudes that consisted of purging the administration from each Hamallist ${ }^{21}$, Rougier and Pierre Boisson who were respectively the Governors of the colonial Sudanin 1937 and Dakar in 1941, implicitly acknowledged in fact that the colonial police was unable to defeat the Sheriff Hamallah.

From 1940 to 1950, the failure of imperial stratagems was turned into a repression against the Sheikh Hamallah and his followers. That cruel violence was highlighting how weak was the French colonial State in West Africa to tame the movement despite the absence of his founding member due to his deportation to Algeria in 1940.

\section{Conclusion}

The difficulties underwent by the machinery of the imperial police while trying to keep a watch over an "indigenous" and religious dynamism, bring it under its york and also do violence against it when needed, showing the heuristic relevance of a theoretical position aiming at renewing the debate about the issue of indigenous people opposition to the French occupancy of Africa in the 20th century. This targeted in fine to

\footnotetext{
18 The man who used to bring to the Sheriff Hamallah the letters he was intended to when he was arrested in Adzopé (1930-1935).

${ }^{19}$ Interview with Malamine Cissé in Gagnoa, July 15th 2014.

${ }^{20}$ (CAOM, Aff. Pol. 2258-3. Paris, December 14th 1935. Notes from Islamic Affairs.)

${ }^{21}$ Non listed Archives of the circle of Nioro. Dakar, April 30th 1941. Telegram-letter. Pierre Boisson, High commissioner to the Governor of Sudan.
} 
state in the light the strategies used by dominated people on a perspective of intelligence, even of reinterpreting the relation of domination during colonial periods.

The Hamallists' ability and the effectiveness of their information network to anticipate the plans meant by the colonial administration for fighting against them, call into question the historical and classical perception about imperial domination. This results to what Romain Bertrand calls the story of "ways" those dominated people driven to be onlookers in a fate they have no hold over, look at the greatness of Europe (Bertrand, 2011, p. 12).

The monopoly the colonial State on information questioned by and embodied in the effectiveness of the Hamallist network to defeat institutional Intelligence services, raises the issue of the social and cultural indexes those people made use of.

Under the light of that relation, let us look at one way African traditional societies function. Networks of family ties and alliances and the belonging to a collective symbolic imagination are some remarkable identities highly emphasized in those societies. Owing to that, various and multiethnic people showed at first sight their great sense of solidarity to the Sheriff Hamallah in his conflict against the French administration.

In 1940-1950, while going back to the "all movements have to be cracked down" policy they had already used to fight against the Sheikh Hamallah and his brotherhood in 1920-1935, the French imperialism was underscoring its limits to impede the extension of the Hamallist network. Once more, in the fighting for independences, the network will satisfactorily help the African Democratic Party (ADP).

\section{Sources}

\section{Oral Sources}

Ahmadou Hampaté Bah interviewed by El Hadj Sacko. Oral tradition dictated by A. H. Bâ to H. Heckmann (Shorthand notes, then typed up), on June 15th 1969 (at Villa d'Avray).

Interview with Seydina Oumar Cisse in Kayes and Bamako (Mali) in March and April, 2000.

Interview with Malamine Cisse in Gagnoa (Cote d'Ivoire) in July 15, 2014.

\section{Colonial Archive Sources}

\section{The Malian Public Record Office. Koulouba}

$4^{\mathrm{E}} 4$. Political reports. Letter from December 21st 1925.

$4^{\mathrm{e}} 26$. The report of inquiries of the circle of Nioro, July 1937. Confidential.

$4^{\mathrm{E}} 4$ letter $\mathrm{n}^{\circ} \mathrm{A}-478$ from November 25 th 1925 . Sent by the Governor of the colony to the Commander of the circle of Nara.

$4^{\mathrm{E}} 4$ letter $\mathrm{n}^{\circ} \mathrm{A}-479$ from November 25 th 1925 . Sent by the Governor of the colony to the Commander of the circle of Bamako.

$4^{\mathrm{E}}$ 4. A copy of the registration form concerning the man who is called Sheikh Aladji Tambadou, registration started on September 1st 1925.

$4^{\mathrm{E}} 24$ Telegram-letter. The Circle of Nema to the Subdivision of Mourdiah, ${ }^{\circ} 80 \mathrm{C} / \mathrm{C}$ from August 18th 1937.

1F88. August 23, 1937. From the Governor of Sudan to the Governor General of Senegal. Confidential. From Corot, the commander of the circle of Nioro to Rougier, Governor in Koulouba.

$1^{\mathrm{E}} 2$. The general report tackling the political face of Sudan in March-April 1943. 


\section{Records of the Circle of Nioro. Non Listed}

The circle of Nioro. August 23rd 1937. From the Commander of the circle of Nioro to the Governor of Sudan. Koulouba. Reference: letter n`534 A.P. from July 21st 1937 concerning the Sheriff Hamallah. Confidential.

Inquiries. Stamped SECRET. File collected by the Administrator of the circle of Nioro at the Investigation Department of Bamako (indigenous people registration forms).

From the Commander of the circle of Nioro to the Governor of Sudan. Koulouba. Reference: letter n ${ }^{\circ} 534$ A.P from July 21st 1937 concerning the Sheriff Hamallah. Confidential. Non listed. Nioro, August 23rd 1937.

The Surveillance of Islam. The setting up of an index of Muslim proselytism in French Colonies of West Africa. The Governor General to the Governor-Lieutenants of colonies and to the Commissioner of the Governor General in Mauritania. Dakar, December 26th 1911.

Confidential circular of the Governor General of French colonies of West Africa to the Governor-Lieutenants of colonies of the group and to the administrator of the district of Dakar. Dakar, March 30, 1930.

\section{The Senegalese Public Record Office}

The Senegalese Public Record Office 15G103. Hamallah's registration form, December 31, 1911.

The Senegalese Public Record Office 19G23 (108). Report about the indigenous people mindset in colonial Sudan from the Captain P. J. ANDRE, Responsible for the Intelligence Services and Islamic affairs. (The carrying out of the order $n^{\circ} 847$ from the Governor General). Koulikoro, August 10th 1923.

\section{The Ivorian Public Record Office}

X-13-253-9245. Political prisoners deported from Sudan and Mauritania to Cote d'Ivoire. 1930-1934. Telegram-letter $\mathrm{n}^{\circ} 394$ from the Lieutenant-governor of Cote d'Ivoire to the Administrator of Abengourou. Bingerville, November 17th 1934.

XIII-30-16/95 $\mathrm{N}^{\mathrm{o}} 67$ The translated version of a letter written in Arabic sent by Yacouba Sylla to the political prisoner Abdourahamane Tandia.

\section{References}

BERTRAND Romain. (2002). L'histoire à parts égales. Récits d'une rencontre Orient-Occident (XVIe-XVIIe siècle). Paris: Editions du Seuil.

BRUNET-La Ruche Bénédicte. (2012). Discipliner les villes coloniales: la police et l'ordre urbain au Dahomey pendant l'entre-deux-guerres. Criminocorpus, Histoire de la police, available online on January 13, 2012, http://criminocorpus.revues.org/1678 (accessed on October 17, 2014).

FREMEAUX Jacques. (1993). Les bureaux arabes dans l'Algérie de la conquête. Paris: Destins croisés. Collection supervised by Bernard Lauzanne.

JOLY Vincent. (1997). La réconciliation de Nioro (septembre 1937): un tournant dans la politique musulmane au Soudan français? In ROBINSON David et TRIAUD Jean Louis (Ed.), Le temps des marabouts. Itinéraires et stratégies islamiques en Afrique occidentale française, v.1880-1960 (pp. 361-372). Paris: Karthala.

LAUNAY Robert and SOARES Benjamin F. (2009). La formation "d'une sphère islamique" en Afrique occidentale française (1895-1958). In Gilles Holder (Ed.), L'islam, nouvel espace public (pp. 63-100). Paris: Karthala.

PIGA Adriana. (2006). La hamaliyya de Nioro du Sahel. Politique coloniale et identité islamique. In Adriana Piga, Les voies du soufisme au sud du Sahara, Parcours historiques et anthropologiques (pp. 191-218). Paris: Karthala.

PONDOPOULO Anna. (2012). Un parcours en compagnie de Jean-Louis Triaud. In GOERG Odile et PONDOPOULO Anna (dir.), Islam et sociétés en Afrique subsaharienne à l'épreuve de l'histoire. Un parcours en compagnie de Jean-Louis Triaud (pp. 5-14). Paris: Karthala. 
SAVADOGO Boukary Mathias. (2012). Les rapports du capitaine André (1923) et le déclenchement de la répression contre la Tijaniyya Hamawiyya. In GOERG Odile et PONDOPOULO Anna (dir.), Islam et sociétés en Afrique subsaharienne à l'épreuve de l'histoire. Un parcours en compagnie de Jean-Louis Triaud (pp. 172-185). Paris: Karthala.

TRAORE Alioune. (1983). Islam et colonisation en Afrique. Cheikh Hamahoullah, homme de foi et résistant. Paris: Maisonneuve et Larose. 